NBER WORKING PAPER SERIES

THE THEORY AND MEASUREMENT OF MACROECONOMIC DISEQUILIBRIUM IN CENTRALLY PLANNED ECONOMIES

Richard Portes

Working Paper No. 1875

\author{
NATIONAL BUREAU OF ECONOMIC RESEARCH \\ 1050 Massachusetts Avenue \\ Cambridge, MA 02138 \\ March 1986
}

The author is Director of the Centre for Economic Policy Research, London; Professor of Economics, University of London; and Directeur d'Etudes Associe. Ecole des Hautes Etudes en Sciences Sociales, Paris. My research on this topic has been supported by the Economic and Social Research Council, most recently under grant B00230048. I have benefited greatly from collaborative work on the problems discussed here with Richard Quandt, David Winter, and Stephen Yeo, none of whom bears any responsibility for this paper. Nor do those who have commented on the paper, including Joe Brada, Wojtek Charemza, Paul Hare, Ed Hewett, Alec Nove, and Tom Wolf. The paper was written for a Festschrift in honor of Franklyn Holzman. The present version is a revision of Birkbeck Discussion Paper in Economics, No. 161, October 1984. The research reported here is part of the NBER's research program in International Studies. Any opinions expressed are those of the author and not those of the National Bureau of Economic Research. 
The Theory and Measurement of Macroeconomic Disequilibrium in Centrally Planned Economies

ABSTRACT

The paper considers issues in recent research on macroeconomic equilibrium in centrally planned economies. I defend the explicit aggregative, macroeconomic approach in theory. institutional relationships and measurement. It has offered a fresh, coherent framework for the analysis of many CPE phenomena, opened up a range of possibilities for empirical investigation, and generated several important spinoffs: work on planners. behaviour, insights into CPE policy problems of the $1970 \mathrm{~s}$ and early 1980s, which centred on macroeconomic equilibrium and threats to it; and some developments in market economy macro theory and econometrics. The quantity-rationing macro model and disequilibrium econometrics give a more useful as well as a more nuanced view of macroeconomic reality in CPEs than the conventional wisdom characterizing them as perpetual "shortage economies".

Richard Portes

Department of Economics Birkbeck College

7-15 Gresse Street Iondon WIP IPA

ENGTAND 


\title{
The Theory and Measurement of Macroecononic Disequilibrium in \\ Centrally Planned Economies
}

\author{
Richard Portes \\ Birkbeck College, University of London \\ and \\ Centre for Economic Policy Research \\ January 1986
}

\section{Introduction}

The line of research I began several years ago into the macroeconomics of the centrally planned economies (CPEs) relies heavily on several important predecessors. Among these, the work of Franklyn Holzman (especially 1956, 1960, 1968) played a major role. This derived not only from the conceptual framework, but also from the open and undogmatic spirit of inquiry underlying it. Though not an econometrician, Holzman knew that theory had to admit confrontation with the data; though not a mathematician, he knew that his understanding of soviet economic institutions hadtobe representable in theoretical terms. His own work

This paper was written for the conference on the soviet Union and Eastern Europe in the World Economy held at the Kennan Institute in Washington, D.C. on 18-19 october 1984 and will appear in a Festschrift for Franklyn Holzman. The present version has been significantly revised. 
quickly became part of the conventional wisdom, but more wise than conventional, and certainly not inhibiting to younger scholars seeking challenging problems. If he thought he had been there before you, he would not hesitate to refer you to the appropriate passage; but this was always good sense rather than exaggerated sensitivity, professional rather than personal. His arguments were vigorous and provocative but not intolerant. This essay is offered in the same spirit.

The motivation for this research on CPE macroeconomics was to elucidate the general problem of macroeconomic equilibrium and, in a specific application, to evaluate the evidence for repressed inflation in the Soviet-type economies of Eastern Europe. This empirical testing required a more elaborate and general macroeconomics than was then available for the CPEs. A prerequisite was to clarify the appropriate concept of "equilibrium" (see Muellbauer and Portes, 1978, for market economies, and Dlouhy, 1984, in the CPE context). An equilibrium with quantity rationing is a state in which markets do not clear, but the economy is at rest, and we can in principle measure the magnitude of "disequilibrium" in terms of the distance from a market-clearing allocation or price vector. Similarly, Kornai ( 1980$)$ discusses a self-reproducing equilibrium state of an economy characterized by pervasive shortages which he subsequently seeks to measure (1982). 
A corresponding theoretical framework is that of recent nonWalrasian general equilibrium macroeconomics, which has stressed the need for consistent microeconomic foundations. To call this the "Clower (1965) - Barro-Grossman (1971, 1974) school" is perhaps too selective and omits some key elements which appear in the sequence Hansen (1951) - Benassy (1975) - Grandmont-Laroque (1976) - Malinvaud (1977) - Muellbauer-Portes (1978) - NearyStiglitz (1983), such as the aggregation problem and expectations of quantity constraints.

Any application to socialist CPEs of contemporary neoclassical theory, developed in and for capitalist market economies, must be informed by a thorough knowledge of East European economies and their institutions. Those of us who, like Franklyn Holzman, served our apprenticeships with detalled studies of particular CPEs (and their languages) can well understand that this is a major reason why this field of economics attracts relatively few young scholars. Without that background, however, one cannot sensibly choose the simplifying assumptions required to get any useful theorizing off the ground. Even with it, one may take a set of assumptions which are not universally regarded as "realistic". But reasonable and well-informed economists can differ (indeed, agree to differ) on the important and justifiable simplifications. These will in any case depend on the objectives of the particular model. One modeller's choice of assumpions that seem prima facie inappropriate to another may not reflect ignorance or disregard of the relevant institutions. Serious 
criticism requires demonstrating rigorously either the inconsistency of the assumptions or (with evidence) that they lead to inappropriate conclusions.

The macroeconomics of CPEs has attracted more than its share of unsupported assertions, purely a priori reasoning, "stylized facts" not based on the data, and confident, elaborate verbal arguments founded on the most casual empiricism. For a theorist to use "obviously" in argument or to dismiss empirical results or "absurd" is only one level below offering various general qualitative considerations to support an essentially quantitative proposition. This is no longer acceptable. We have for some time had reasonably long and fairly reliable macroeconomic time series for several CPEs. Empirical assertions about the behaviour of CPE households, planners, enterprises or markets should not be taken seriously unless they are supported by the data. Disagreements over empirical issues can be resolved only by testing well-defined hypotheses.

All this does not deny but rather supports the validity of alternative approaches. One is a variety of institutionalism, seeking distinctive general lessons in the specificities of socialist planning, finding those generalities in a formalism which is not primarily directed towards proving theorems or generating testable hypotheses. The symbols used in this formalism are often difficult to translate into measurable variables, and the research strategy comes close to rejecting the standard model- 
hypotheses-tests procedure (Kornai 1980, 1ess so in 1982). It yields insights nevertheless, as do a range of models and empirical work within the more standard neoclassical canons (see be 1 ow).

The following sections consider issues raised by my own research programme on macroeconomic equilibrium in CPEs and comparisons with alternative views. I defend the explicit aggregative, macroeconomic approach in theory, institutional relationships and measurement. It has offered a fresh, coherent framework for the analysis of many CPE phenomena, opened up a range of possibilities for empirical investigation, and generated several important spinoffs: work on planners' behaviour: insights into CPE policy problems of the 1970 s and early 1980 s, which centred on macroeconomic equilibrium and threats to it; and some developments in market economy macro theory and econometrics.

\section{Theory}

I take as common ground for this survey that CPEs exhibit behavioural as well as technological regularities; stable economic behaviour of CPE households, planners and enterprises is part of our maintained hypothesis. I limit the discussion here to the consumer goods and labour markets, while recognising that relations between enterprises and planners and disequilibria 
within the state productive sector have been the subject of much interesting theory and empirical work (e.g., on investment "cycles"). I accept the consensus from this work that CPEs normally exhibit generalized excess real demand (qualified by the non-market character of transactions) in the state productive sector, for intermediate and investment goods. It is not relevant here, however, to assess the relative importance of overly taut initial plans (including systematic "optimism" about unknown data and exogenous shocks) and systemic features like an output-based incentive system.

Both demand for and supply of consumption goods and labour will depend on events in the state productive sector. Total demand for consumption goods will be affected indirectly by events in the labour market and directly by the demand from state enterprises for some consumption goods. The latter is probably of secondary importance (Kornai, 1980, p. 497), but the interplay between planners, enterprises and banks which determines wage plan (over)fulfilment is a key element of the story (Holzman, 1956, 1960; Portes, 1983). We discuss it and the supply side further below. Whether they do jointly yield excess demand is an empirical question. To answer it does require specifying demand and supply functions and hence the transmission of behaviour in the state productive sector through those functions, but not the internal processes which generate that behaviour. 
Although the labour market is equally important, both theory and data are weaker, so assessing the nature and extent of disequilibrium there is much less advanced. This is particularly regrettable since the spillovers from the consumption goods market onto labour supply could in principle reveal significant information about the former, although evaluating it might be difficult too (Portes, 1974 ; Wiles and Rostowski, 1979). Moreover, one of the chief reasons why the planners themselves as well as external observers should be interested in consumption goods market disequilibrium is this spillover on the incentive to work (Hansen, 1951; Galbraith, 1952). Excess demand willalso typically result in an inefficient allocation of goods and affect the distribution of real income: both will concern the planners.

\subsection{Definitions}

What is macroeconomic disequilibrium and how do we recognize it? When prices are free to vary, even with some stickiness, we expect movements of the price level to provide evidence of excess demand or supply, even if such price flexibility may not eliminate the disequilibrium (as it does not in market economy hyperinflations and as Kornai, 1980, expects for CPEs). When prices are endogenously sticky or controlled, we may observe either hidden or repressed inflation ( $I$ consider here only positive excess demand). Some carelessly conflate the two (Winiecki, 1985), but this unnecessarily gives up a useful conceptual and practical distinction. A price index may be 
falsified, may cover an unrepresentative basket of goods, and may not reflect quality change; any of these phenomena may "hide" underlying inflation, i.e., a rise in an accurately calculated, appropriately weighted, quality-corrected price index. Repressed inflation, on the other hand, is simply "a situation in which, at existing wages and prices, the aggregate demands for current output and labour services exceed the corresponding aggregate supplies...[so] purchases of goods and labour services are rationed (Barro and Grossman, 1974, p. 87)." This excess real demand (a flow) is the "inflationary gap" whose consequences for prices are suppressed. But the "gap" terminology can be misleading, and it is at best unhelpful to say that rationing "hides" inflation (rather than suppresses it), since this suggests that the price level, appropriately defined as above, is actually increasing. That usage also obscures an important point, that repressed inflation may cause hidden inflation.

Rationing is one consequence of repressed inflation. At the aggregate level, its mirror image is forced saving (note that as a global monetary magnitude, this is inherenty an aggregate concept). This is a flow of saving rather than a stock (the socalled "monetary overhang"). Flows are determined by desired and actual stocks and by many other factors. When we investigate equilibrium on the consumption goods market, we look at the balance of flow demand and supply, of which the stocks of household liquid assets and sellers' inventories are only partial determinants. 
Simply put, forced saving is that part of their flow of disposable income which households would like to spend but cannot. Indeed, putting it so simply immediately prompts the question why it should ever occur - forcing people to save sounds odd, rather like pushing on a string. There are only two reasons: households voluntarily (maximizing subject to available supplies of goods) substitute (expected) future consumption for unavailable current consumption; or they involuntarily supply more labour than they would like, i.e., they are constrained from reducing their labour supply and hence income as much as the reduced (by rationing) marginal utility of income would otherwise induce. Note, therefore, that if there actually has been chronic, sustained repressed inflation since the beginning of central planning and households rationally expect it to continue, the "voluntary" component of forced saving will be negligible, and its on 1 y cause must be inhibitions on cutting labour supply.

Households can of course reduce their labour supply qualitatively ("effort") as well as quantitatively, or quantitatively in ways that will not be recorded in the data. This in no way affects the essential argument. nor theoretical modeling of it: Excess demand for consumption goods should have a spillover effect in reducing effective (quality-corrected) labour supply, and hence output; this is the basis of the "supply multiplier".

How important is this effect? Wiles and Rostowski (1979) query it on mainly a priori grounds, except insofar as they claim that 
wage-elasticities of labour supply are observed to be low or negative. A simple calculation from equation (4) of Portes (1981) shows, however, that the response of labour supply to (rationed) consumption will depend on the difference between the wage-elasticities of unconstrained and constrained labour supply functions. These are likely to vary together, so the WilesRostowski claim shows nothing. Kornai recognizes that "the issue is basically an empirical one," but then without examining evidence asserts "that the intensity of shortage is not one of the variables explaining labour supply either positively or negatively (1980, p. 479)." My prejudice goes the opposite way, along with Hansen and Galbraith; but we should remain agnostic until the evidence is in. Howard's (1976) results suggest a significant effect, but I cannot accept them (nor his general argument) for the reasons suggested in katz (1979), Nissanke (1979), and Portes and Winter (1980).

In theory, then, how should we measure macroeconomic disequilibrium in the consumption goods market? The definitions above suggest trying to measure the difference between aggregate demand and aggregate supply, or alternatively, forced saving (again, the difference between actual and desired holdings of financial assets is not what we want, although it is one determinant of excess demand). Three major questions immediately arise of which we mention two and examine the third at length. First, should we use "notional" or "effective" demand and supply? The quantity-rationing macro literature suggests the 1 atter 
(Muellbauer and Portes: 1978) but there are counterarguments. Second, the formal or informal rationing schemes used under excess demand may be "manipulable", in the sense that a household may influence the amount it receives, in particular by presenting a demand exceeding what it actually wants, knowing that the probability of success or the fraction of revealed demand which it will achieve is less than unity. This would exaggerate measured excess demand. Weinrich (1984) considers the theoretically appropriate measure of excess demand in these circumstances for the stochastic rationing case, but we have as yet no practical procedure for making the correction (but see Burkett, 1985, who deals empirically with the converse, the "discouraged consumer effect").

\subsection{The Aggregation Problem}

Much the most fundamental and important issue is the aggregation problem. Tartarin (1982) goes sofar as to say, "Only micro disequilibria are real, macro disequilibrium is an artifact which exists only in the domain of the national accounts." This suggests not only that our measurement problem is in principle insoluble - even the most ambitious assistant professor might decline a research grant for measuring statistical artifacts but also that neither monetary theory nor macroeconomic policy are of any interest in considering disequilibria, at least in CPEs. Having written on both (Portes, 1980,1983), I clearly do believe there are interesting theoretical propositions and policy 
interpretations in the aggregative economics of CPEs which involve macroeconomic disequilibrium in essential ways.

Then how can we distinguish between distorted relative prices and macroeconomic-monetary causes of the phenomena we identify with disequilibrium in CPEs? We have suggested thought experiments to clarify the theoretical distinction (Portes and Winter, 1980), and in policy terms we might consider the separate responsibilities of the Price office and the Ministry of Finance (monobank) and Ministry of Labour. Macroeconomic policy cannot suffice to deal with problems created by the structure of relative prices, the system of incentives, etc.

operationally, however, we must come to terms with the problem of identifying aggregate excess demand when at the micro level, there are both positive and negative excess demands, shortages and slacks. Kornai insists that they must remain disaggregated, as vectors, and that it would be a "grave mistake...to 'net out" shortage and slack...(1980, p. 45)." He would accept that "aggregate excess demand" might be we11-defined in an economy whose "normal state" was not pervasive shortage. In a "chronic shortage economy," however, "Buyers have adjusted their attitudes to chronic shortages...where massive forced substitution, forced spending and queueing are to be found...aggregate excess demand is not an operationa 1 category...(1980, p. 477)." 
The key point in this argument is the change in buyers' behaviour, which we interpret to mean that their quantity (constraint) expectations are different. These expectations are arguments of their demand functions, but the preferences underlying those functions are not altered by chronic shortage. Consider the case of long-run mass unemployment. Workers will adjust, in the sense of changing quantity (constraint) expectations. The "discouraged worker" effect is one manifestation: some people will leave the labour market. Others will substitute (accept) inferior jobs for those preferred but unavailable at existing relative wages. Liquidity preference and consumption behaviour are also affected. We do not normally suppose, however, that individual labour supply functions have altered. Should we say that aggregate excess supply of 1 abour is not in these circumstances an "operational category"? If so, how do we characterize macroeconomic relationships in the $1930 \mathrm{~s}$ ? Moreover, would not the "vector of disaggregated indicators" with which Kornai characterizes shortage also be affected by quantity expectations? We would agree that aggregate excess demand cannot be defined independently of the "normal state" of the economy, on the understanding that this includes the quantity constraint expectations, if any, held by agents in the economy.

The existence of forced substitution with excess demand is not a major theoretical problem. After a11, at the aggregate leve1, both forced saving and the response of labour supply to a constraint in the goods market are examples of forced substitu- 
tion. Spillover effects of this kind have been modelled extensively, and all quantity-rationing macro deals with transactions taking place at "false" (disequilibrium) prices. In practice, forced substitution is a cause for worry only if elasticities of substitution in demand are low and it is nevertheless extensive. Although it is a 1 ways welfare-reducing, the importance of that effect will depend on the elasticities, and it should not in any case stop us from doing applied macroeconomics.

In seeking to measure aggregate excess demand, we cannot avoid "netting out" shortages and slacks. This does indeed present a problem in theory, as suggested by the Barro-Grossman definition of repressed inflation quoted above. In a two-market model, they require that both be in excess demand. This stipulation that the vector of excess demands be semipositive (so no "netting out" at false prices is necessary) goes back at least as far as Hansen (1951), and it is reflected in the consistent usage of the quantity-rationing macro literature: excess demand for goods with excess supply of labour is "classical unemployment", a quite different regime (the converse is "underconsumption"). In practice, however, the early period of central planning, when most goods were in excess demand and labour in excess supply, is better characterised as "repressed inflation on the goods market" (Kornai, 1980, sec. $11.7 ; 1982$, pp. 102-108).

We a 11 need to use macroeconomic aggregates, even Janos Kornai discussing CPEs (1980, Secs. 16.2-16.5, 17.6, 18.5, 21.1-21.2, 
and Chap. 19 and the explicit macromodelling of 1982, passim). Yet he would take the aggregation problem as sufficient reason to reject the central concepts of quantity-rationing macroeconomics: the "short-side rule" (that all agents on the short side of the market achieve their desired transactions), the "minimum condition" (that the aggregate quantity transacted is the minimimum of supply and demand), and "discrete switching" between excess supply and excess demand regimes. Even for market economies not subject to chronic shortages, however, it is quite impossible to do applied macroeconomics with a purist approach to the aggregation problem (see Deaton and Muellbauer, Chap. 6 and sec. 12.1). Instead, one must simply do macroeconomics carefully, always remaining open to empirical evidence (not a priori assertion) that its results are contradicted when one allows explicitly for microdisequilibria. In fact, however, Burkett's (1985) study using Kornai's concepts gives results perfectly consistent with our own; see Sec. 3.4 below.

One internally consistent way of approaching the problem in our context is "smoothing by aggregation", whose lengthy pedigree is sketched by Muellbauer (1978). If we aggregate over many micro labour markets, for example, some in excess supply and some in excess demand, we find that total demand is the sum of employment and vacancies, total supply is the sum of employment and unemployment, so total excess demand equals vacancies minus unemployment; as the real wage rises, aggregate excess demand falls in a continuous manner, with a smooth unemployment- 
vacancies tradeoff. Aggregate employment will always lie to the left of the wedge formed by the aggregate demand and supply curves.

A diagram in Portes and Winter (1980) applies this to the aggregate consumption goods market in CPEs. Note that the larger the elasticities of substitution, and hence the stronger is forced substitution, the closer will observed aggregate behaviour approximate the underlying aggregate demand and supply curves which would be observed in full Walrasian equilibrium, and consequently the more suitable is the discrete-switching, mincondition empirical model. The "smoothing by aggregation" approach has been developed further by Malinvaud (1981), Kooiman (1984), Gourieroux and Laroque (1985) and Martin (1986). It appears especially promising for applications where there are data indicating the proportions of micromarkets in excess demand and in excess supply.

\subsection{Macroeconomic Models}

I do not have space to discuss in detail the alternative complete models within which one might consider the theory and measurement of macroeconomic disequilibrium in CPEs. I have set out my own in Portes (1979,1981); Wolf (1985) discusses it and others. It has only two aggregate markets, for consumption goods and labour; only households hold money; there is no "parallel" (flex-price) market; there are only two categories of agents, households and 
planners; inventories and foreign trade are incorporated, but to only a limited extent; households' quantity expectations are not treated explicitly; and there is no attempt to specify a complete macroeconometric model based on this theoretical framework. It nevertheless provides a coherent theoretical representation of macroeconomic disequilibrium and an adequate basis for measuring it in the consumption goods market, as we have done. Adding the specification of the plan construction process developed further in Portes et a1. (1983, 1984a), Dlouhy (1984) suggests three major similarities between this model and that of kornai (1982) both are non-Walrasian general equilibrium models; both deal with the "real" and the "control" spheres; and both have endogenous mechanisms for adjustment towards an equilibrium. I would add that Kornai ( 1980, secs. $19.4-19.6)$ gives a simi 19 r representation of plan construction, especially in assuming that the planners are rational and do try ex ante to avoid excess demand, ceteris paribus. Stupnicki (1985) carefully compares my mode1 with Kornai.

Several alternative models have been proposed with different assumptions. Pickersgil1(1980a), Duchene (1984), Henin (1984) and Nuti (1985) explore the implications of a parallel market. Hare (1982) incorporates some of Kornai's ideas into the framework of Malinvaud (1977), which is similar to our own. Brada ( 1982 ) assumes that enterprises a 1 so hold money. Hulyak ( 1983$)$ specifies a larger macroeconometric mode 1 whose consumption block resembles our treatment. There remains much 
work to be done with quantity constraint expectations, inventories, and foreign trade. For our purposes, however, I see little advantage in breaking up the state productive sector into planners and enterprises and modelling the interaction between them. This is clearly essential in mode11ing investment behaviour, but not for the consumption goods market. I follow Campbe11 (1970) in be1ieving that "the state production establishment [SPE] can best be considered as a single gigantic firm under the unified direction of the planners...intra-spE transactions...1acking the market characteristics of those between households and the SPE, are of less interest from the point of view of pricing and macroeconomic equilibrium (pp. 255. $258) . "$

There are no general, a priori guidelines for the essential elements of a CPE macro mode1. A11 simplifying assumptons are "wrong", so one chooses a minimal coherent set sufficient for one's objectives. Mine were to formalize some propositions and to provide a basis for econometric hypothesis testing. I would claim that the institutional framework is just about rich enough for the purpose and not seriously flawed. Some have queried the basic strategy of applying to CPEs the neoclassical macro theory, in its quantity-rationing version, as well as disequilibrium econometrics. I believe, however, that they and a simple monetarism are often better suited to cPEs than to comparable market economies. 


\subsection{Behaviour of Households and Planners}

Others take a similar line in this context. Wiles and Rostowski (1979) describe the institutional characteristics of CPEs that "led him [Portes] correctly to suppose that western micro- and macroeconomics...would be fully applicable to households in CPEs (p.62)." Pickersgill(1983) states, "The work I have done so far increases my confidence in the similarity of behavioural relationships and therefore of the appropriateness of using Western methodologies in the study of soviet household behaviour," and Asselain (1981) takes the same view of saving behaviour in STEs.

Modelling the planners is more difficult, and there are no obvious analogies in neoclassical theory. We extend our basic plan-construction process with an explicit planners' loss function (Portes et al., 1983), which incorporates a steady growth objective like that in Kornai (1980, p. 490, and 1982). This appears to be successful empirically.

on the other hand, Kornai specifically rejects the analogy between repressed inflation in a fix-price capitalist economy and the "suction system" of a socialist economy, "for the latter has different institutional condtions and its behavioral regularities are therefore different, too (1980, p. 558)." of the differences he cites, however, all but one relate to aspects of firms' behaviour not relevant to the consumption goods market, 
while the last concerns the adjustment of buyers' behaviour to shortage, discussed above. I therefore maintain that this analogy is indeed instructive, and our intuition is not misleading.

Although Kornai does accept the symmetry between Keynesian unemployment and repressed inflation in a capitalist economy, he rejects any symmetry between the former in a capitalist economy and the latter in a socialist economy (p. 478). He maintains that suction in a socialist economy is sui generis because its "mode of operation, its management system, and the behavior of the agents within it have adjusted to chronic shortage. which is continuously maintained by the institutional relationships (p. 478)." Again, we suggest above that similar adaptation occurs in long-run mass unemployment, and one might think that Marxists would go even further to say that the institutional relationships of a capitalist economy are such as to maintain unemployment substantially above the natural rate continuously.

Moreover, just as the rate of unemployment is useful though crude as an index of excess supply in the labour markets of capitalist countries and is usable in cross-country comparisons despite data comparability problems, so we can construct a similar index for excess demand on the consumption goods markets of CPEs. We take the demand and supply functions obtained by disequilibrium estimation (see below), calculate "fitted" demand and supply for each year, and take their difference as a percentage of observed 
consumption (Portes and Winter, 1980 - an alternative version, based on stochastic simulation of the fitted functions, is calculated in Portes et a1. 1983). This measure can also be used in intertemporal and international comparisons.

Finally, the relations between CPE institutions and the theory of macroeconomic equilibrium appear in my analysis of how excess demand is generated. reproduced and controlled (1977a. 1983). The planners' objectives and the enterprise incentive system generate taut plans in the state productive sector and pressure to overfulfill them, and these forces are exacerbated by errors and exogenous shocks. This may affect the demand for and supply of consumer goods, but less than is commonly thought. Although I accept much of Kornai's analysis of plan construction for consumption goods (1980, Secs. 16.1-16.4), my model explicitly admits the possibility of an ex ante "unbalanced" plan. This gives some insights but has no effect on the empirical work, nor does the precise source of consumpton goods market disequilibrium.

The view that consumption plans are chronically unrealistic (unbalanced, optimlstic) and hence underfulfilled (Wintecki, 1985) is decisively rejected by aggregate time-series data for actual and planned consumption in three CPEs. Some argue a priori that supply (CS) will always fall short of the plan (C*) and demand (CD) w111 always exceed it, so CS<C*<CD. Then C m in (CD, CS) would suggest that actual $C<C^{*}$ always. In Poland, however, 
we find $C>C *$ for 10 of the 19 years 1957-75, until the Gierek policies ensured $C<C *$ throughout the second half of the $1970 \mathrm{~s}$. For Czechoslovakia. C $>C *$ in 15 of the 24 years 1957-80: and in Hungary, $C>C *$ in 11 of the 19 years 1957-75, then once more in the following quinquennium. Similarly, Kornai's general view that wage plans are fulfilled very closely (1980, sec. 16.1) is borne out by Farrell's (1975) study of Poland. He shows that the average amount by which the plan was exceeded in 1957-70 was $2.6 \%$, although Poland is generally thought to have been rather lax in monetary control.

I cannot accept Kornal's views, however, on the roles of relative prices and of price rigidity in creating and maintaining shortages. He cites for example. groups of products for which the relationship between price and average cost goes in the opposite sense of the intensity of shortage as "a new empirical argument against the view that 'shortage exists when relative prices are too low' (1980, p. 500)." That argument ignores the demand side and is hence a glaring non-sequitur. Equaliy, as Gomulka (1985) points out, Kornal's assertion that "there is no behavioral regularity ensuring that a rise in the price level of consumption goods eliminates the shortage (p. 497)" simply does not follow from the a priori arguments given (no evidence is cited); and it is inconsistent with his view that the household faces a "hard" budget constraint. Yet these are key elements in his downgrading of the role of prices and money because of the systemic features and institutional regularities in a shortage 
economy. I regard them as unsupported assertions.

\section{Measurement}

Only empirical testing can ultimately resolve the basic issues to which this analysis is directed. Assertion and casual empiricism will not do. To arrive (ideally) at an agreed interpretation of the results of such tests, however, the theoretical framework within which they are carried out must be broadly agreed as well. The discussion above is intended to extend the area of agreement.

\subsection{Econometric Results}

Our own examination of the data, tests. results and conclusions are set out in a series of papers (Portes, 1974, 1977a; with Winter, 1977,1978,1980; et a1., 1983,1984a,1984b,1985). I shall not at tempt to summarize them, although I shall reply below to the relatively few specific criticisms which they have attracted. There seems to be an irresistible temptation, however, for those who reject our methods or our conclusions to misrepresent both by setting up straw men which can easily be tumbled without taking the effort to address specific issues of theory, econometrics or data. It may therefore be useful simply to quote for the record a few summary statements from these papers : 
1. "..there was significant inflation, both repressed and sometimes open, in the CPEs until that time [mid-1950s]. Moreover, there may have been brief episodes in particular countries during particular periods since then...[but] there is no evidence of sustained repressed inflation in any of the Soviet-type CPEs since the mid-1950s (Portes, 1974)."

2. "We have specified and estimated [in an equilibrium framework] household demand for money and savings functions in four CPEs. The successful estimation...and the plausibility of the estimates support our underlying hypothesis that the behaviour of the household sector in CPEs can be analysed using the same methods that are used for this sector in western countries...[and] testify to the quality of the data...The residuals can tell us little about the overall degree of market equilibrium during the period, however...[and] we can draw no further conclusions about repressed inflation until we treat both sides of the market in a disequilibrium framework (P-W 1978 , p. 17 )."

3. "...Begin with the estimated probabilities [that an observation was generated by an excess demand regime]...simply allocating each year...on the basis of [the probability exceeding or falling short of] 0.5...[indicates] excess supply was the dominant regime in three out of the four countries. This is a very crude description of the results, however. More precise 
efforts at hypothesis testing are made [below, from which]...we cannot draw strong, unambiguous empirical conclusions...[but] we believe that the evidence...clearly justifies rejecting the hypothesis of sustained repressed inflation in the market for consumption goods and services since the mid-1950s [to the mid$1970 \mathrm{~s}$ ] in our four CPEs (P-W 1980, pp. 149, 155-6)." Note that we have not stated any such view for the period since the mid$1970 \mathrm{~s}$, especially in respect of the USSR (to which we cannot extend our econometric analysis because of data problems); and other work suggests rising pressure of demand on the soviet consumption goods market in recent years (see below).

Contrast our actual conclusions with wiles and Rostowsk's interpretation of them. "In Portes's view there is no demand inflationary pressure in STEs because of successful planning...(p. 61)." Tartarin (1982): P-W "emphatical1y conclude [that there was] general excess supply (p. 25 )." Kornai (1982): "I shall quote one of their important findings...'On this basis excess supply was the dominant regime in three out of the four countries.' In my opinion [emphasis added], the conclusion is absurd. All four countries should be considered chronic-shortage economies...(p.35)" Such distortion of serious empirical work, with the (widely quoted) dismissal of it as "absurd", is not worthy of reply as such. 


\subsection{Validity of Macroeconometrics for CPEs}

Let us now turn to substance. Kornai rejects from the outset all macroeconometrics for CPE markets in which he believes shortages to be chronic and widespread, for in these circumstances no econometric technique can work: "the inference from glactual trade] to d [initial demand] becones inadmissible (1980, p. 98):" it is a "vain effort" (1982, p. 98). Consider the contrapositive of this proposition, however: If we and others do obtain results which satisfy a priori restrictions drawn from theory as well as conventional econometric criteria, then shortages must be either not widespread or not chronic. Yet this does seem to be the case. The large CPE macroeconometric models of Welfe, Szakolczai, Sujan, Wolfling and others are well-known and not easily dismissible. For careful estimation and hypothesis testing on a smaller scale which seems to yield coherent results on consumption goods markets, we cite (only by way of example) Charemza and Gronicki (1983), Hulyak (1982), Klaus and Rudlovcek (1982), Podkaminer (1982), and Timmer (1982); this work covers Hungary, Poland and Czechoslovakia.

How do we and others obtain well-behaved functions, significant and plausible parameter estimates, reasonable out-of-sample performance, etc.? Are all these results merely statistical artifacts? If one does admit they might have some validity, however, even some of the most cherished "stylized facts" must be queried. Podkaminer (1982), for example, using a model totally 
different from our own. gets results which suggest aggregate excess supply of consumption goods in poland up to the early $1970 \mathrm{~s}$ (revised estimates in Podkaminer, 1984, still allow equality of aggregate demand and supply in the 1 ate 1960s). The conclusion may look rather less"absurd" if reached by various routes with different data sets. K1aus and Rud1ovcek (1982) summarize their results unambiguously: "We strongly believe that global equilibrium at the consumption goods market was the prevalent characteristic of the Czechoslovak economy in the last quarter of the century." others are simply not willing to accept what Kornai regards as obvious: "... we do not find useful (and even realistic) to accept the assumption of permanent (or 'norma1') shortage on these markets [consumption goods and 1 abour ]...(D 1 ouhy, 1984 )."

\subsection{Hidden Inflation and Forced Savings}

We now take a few specific topics before passing to the contributions of disequilibrium macroeconometrics on the one hand and indicators of shortage on the other. First, hidden inflation. Portes (1977a) cites estimates by others of s1ightly over $1 \%$ p.a. for the USSR over two decades. More recent work by Alton et a 1. (1981) shows their "alternative" consumer price index growing faster than the "official implicit consumer price index" by $2.4 \%$ p.a. for Bulgaria, $1.6 \%$ p.a. for Czechoslovakia, 1.3\% p.a. for the GDR, $1.1 \%$ p.a. for Hungary, and $1.6 \%$ p.a. for Poland. These 
are unlikely to be underestimates. They should be contrasted with unsupported remarks like that in Nove (1979) putting hidden inflation in Poland in 1975 at 8\% (which, with official estimates of nominal incomes and the CPI, would suggest that real incomes actually fell in that year!).

Savings behaviour of CPE households has been investigated extensively with conventional methods. Some authors (e.g., Winiecki; 1985) continue the confusions arising from theoretically unjustifiable measures like the ratio of savings (flow) to change in income, or wealth to retail sales (consumption flow), long after Portes (1974, 1977a) and Asselain ( 1981 ) have clearly demonstrated that they give meaningless answers. Thus Asselain shows impeccably that a constant savings rate implies a long period of considerable increase in the wealth-income ratio, if initial stocks are $10 \mathrm{w}$; and that comparing two economies with the same savings rate and rate of growth of real income but different inflation rates, the economy which is inflating faster will exhibit a lower wealth-income ratio. In the view of Wiles and Rostowski, "He [Portes] rightly ridicules the Soviet-type habit of quoting savings/(change in income) as if it were the Keynesian marginal propensity...Portes may even be on secure ground in setting up his judgment against Soviet-type bankers, who are alarmed by the ratio of the stock of liquid savings to the flow of retail trade (1979, pp. 64-65)." 
Serious work on household assets and savings in CPEs seems remarkably unanimous in not showing much evidence of forced saving. Pickersgill(1976) is clear on this for the USSR, but her later time-series results (1980) indicate that there may have been a substantial upward shift in the MPS in the late $1960 \mathrm{~s}$ and early $1970 \mathrm{~s}$ which could show some forced saving. Her crosssection work with ofer (1980) "does not support the proposition that Soviet households save inordinately large amounts of their income for 1 ack of consumer goods and services to purchase," and she expresses similar views in her later survey of both time series and budget study evidence (1983). Asselain's (1981) careful theoretical and empirical analysis leads him to conclude for several CPEs that "The full set of characteristics of a typical situation of forced saving...are thus never found together, and one should not be surprised that econometric work seeks first to test the hypothesis of a savings-income relation of the same type as in Western market economies ( .43 )." Klaus and Rudlovcek (1982) get good results for a standard savings function for Czechoslovakia, 1965-81 the forecasting performance was good, and the saving ratio was not high by internationa 1 comparison and did not seem to depend on supply-side events. Peebles (1981), who constructs estimates of household cash holdings in the USSR, finds an overall trend of decline in the currency to deposit ratio (as elsewhere in Eastern Europe), and that "Soviet liquidity is not excessive (p. 75)" by comparison with other CPEs. There is no agreement among authors, however, on whether we should expect savings rates in CPEs to be lower, 
higher, or about the same as in their market-economy counterparts. It should be stressed that none of these studies pretends to test for excess demand, nor should they be so interpreted. They and the work cited in Sec. 3.2 are simply consistent with taking equilibrium as a working hypothesis.

Kornai (1980) asserts that the "Clower-Barro-Grossman train of thought" provides "theoretical background for the argument" that the "time path of savings in the household sector [can indicate] whether the consumer goods market on the macro-level is in a state of aggregate excess demand or aggregate excess supply (pp. 477-8)." This is puzzling. He is presumably referring to our work, yet the precise object of our analysis in Portes and Winter $(1978,1980)$ is to use the quantity-rationing macro model to show why and how in disequilibrium, this sort of argument may give quite the wrong answer. Even more inexplicable, therefore, is his own use of departures from trend of household savings as one of his indicators of shortage (1982, p. 139) - an aggregate indicator, at that!

\subsection{Disequilibrium Econometrics}

Now we turn to disequilibrium econometrics (see Quandt, 1982, for a survey). Part of the maintained hypothesis is that one observes only the quantity transacted, and that supply and demand are latent variables to be estimated, along with the functions which generate them. Kornai, too, believes that it is impossible 
to separate consumption supply and demand in the observed data, that they are latent variables, and that they combine to determine actual consumption. Yet he concludes that there is only one "consumption function", with both demand-side and supply-side variables on the right-hand side. It is difficult to justify such a quasi-reduced form if one really admits the possibility of disequilibrium. We believe it is preferable to estimate the latent variables directly - they are in principle measureable, as Kornai must agree, since he regards shortage as a latent variable and seeks himself to measure it.

Proper hypothesis testing in this area requires a clear statement of the maintained hypothesis, the null, and the alternative. The maintained hypothesis must explicitly admit an alternative to excess demand - otherwise, it is logically impossible to test for its presence. This fundamental point leads us to reject Howard's (1976) results and to find unhelpful the mode1 of Brada (1982), which in this respect begs the basic question. Our own maintained hypothesis does allow excess demand, equilibrium (on a set of measure zero), and excess supply in the consumption goods market.

In specifying our consumption demand equation, however, we have chosen a "Keynesian" form which lmplicitly assumes that households are constrained in the labour market. This was not an empirical judgment. We chose the Houthakker-Taylor function because we needed a specification which was easy to estimate, did 
not exhaust too many degrees of freedom or require great attention to the error structure, and gave a few clear prior restrictions on the coefficients, violation of which would tell us that something was seriously wrong. This standard function permitted ready international comparisons and avoided difficult data problems. If one were to reject it on the grounds that the estimates will be biased unless there actually was excess supply of labour, one would have also to reject almost all consumption function estimates on Western economies which might ever have experienced "fu11 employment".

As remarked above, our estimates have not been challenged in detail. We ourselves recognize important extensions to the empirical model which should be a high priority for future research: to incorporate foreign trade and inventories. To dispel any misconceptions, we have never used inventory data (which raise great problems - e.g., what is "saleable"?) in our econometric work.

Ours are not the only versions of disequilibrium models for the consumption goods markets of CPEs. Charemza and Quandt (1982) suggest several alternatives; and Charemza and Gronicki (1983) implement a "quasi-disequilibrium" model for Poland. Within the models we use, however, we have performed a wide variety of tests, and both our theoretical framework and our results seem quite robust. For example, it is possible to test the "Kornai hypothesis" of continuous excess demand against our more general 
alternative. our results clearly reject the restriction (Portes, Quandt and Yeo, 1985). Kornai would doubtless reject the test, because he believes that the aggregation problem invalidates any discrete-switching, min-condition mode1. As suggested above, taken too seriously, the aggregation problem inva 1 idates a 11 empirica 1 macroeconomics. On his hypothesis, however, we could never obtain information about the latent consumption demand variable. But it is then inexplicable how we (and others) continue to obtain we11-identified, we11-behaved demand functions, if they do not exist or are in principle unobservable.

John Burkett (1985) has made Kornai operational by ingeniously developing methods for dealing with the "discouraged consumer effect" and with the coexistence of shortage and slack. His specification directly estimates potential demand (allowing for the discouraged consumer effect), total shortage, and tota 1 slack, a 11 separately, a 11 owing for spillovers 1 ike forced substitution. His results, covering five East European countries, are entirely consistent with those we obtained using the category of aggregate excess demand. He finds that total slack exceeds shortage throughout 1957-78 in the GDR and Hungary and for 1956-80 (except 1972) in Poland, while shortage exceeds s 1 ack for 13 of the 24 years 1955-78 in Czechoslovakia. His direct estimates of shortage, net of slack, correlate remarkably we11 with our estimates of aggregate excess demand. Even allowing for potential (but discouraged) demand does not change 
this picture.

Thus Burkett concludes. "One cannot reject the discrete switching hypothesis. Shortages exist but except in the case of Czechoslovakia are usually overshadowed by slack. Potential consumer demand, purged of the discouraged consumer effect, is substantially greater than actual demand but seldom as great as supply. Thus application of techniques suggested by kornai's theory .... can yield conclusions consistent with portes's evidence of prevalent aggregate excess supply". Nuti (1985) claims that "the spurious precision of advanced econometrics ... almost tautologically defines imbalance out of existence." This cavalier approach to rigorous empirical testing is unsubstantiated by any direct criticism of the aggregate discrete switching model, and it is a fortiori rejected by Burkett's results from a model which includes lmbalances at the micro as well as the macro level.

Finally. we turn to Kornai's indicators of shortage. He says we need many of them, at a disaggregated level, in order properly and comprehensively to characterize shortage. Yet he expects the individual indicators to be highly correlated (1982, p. 15). Moreover, he finds his "macro" (synthetic) index of shortage for Hungary close to our own series of estimated excess demands (Portes and winter, 1980). The simple correlation is in fact $r=.604$, and the turning points are quite similar. He regards ours as "invalid", because they are derived from a discrete- 
switching macro mode1. We had argued previously however, on "smoothing by aggregation" grounds, that one could expect a welldefined correspondence of just this kind (P-W 1980), so we were not surprised. Burkett's (1985) results arefurther, perhaps definitive confirmation that our approach using aggregate excess demand produces results which, so far from being "invalid" or "absurd", are in fact consistent with and complementary to more disaggregated methods.

We finish on this reassuring point of agreement. The theoretical and empirical problems of measuring macroeconomic disequilibrium in CPEs may now be somewhat clearer, the areas of agreement and disagreement better defined. The main practical question, with policy implications, is still to distinguish between the effects of excess aggregate demand and distorted relative prices (or other problems like the inadequacies of the distributive network - see Pryor, 1977, Skurski, 1972, and Turcan, 1977). We may be getting closer.

\section{Conciusion}

The line of research surveyed here was originally motivated by scepticism towards the conventional wisdom that the household sector of CPEs has been subject to sustained repressed inflation since central planning began. This conventional wisdom has since been elaborated and defended by Kornai, indeed elevated with considerable flourish into a general characterisation of CPEs as 
"shortage economies". There is much which is stimulating in this analysis, which has gained currency from the worsening macroeconomic disequilibria in some CPEs (especially Poland) since the early $1970 \mathrm{~s}$. But it distorts the facts over the whole period since the early $1950 \mathrm{~s}$ and thereby reinforces confused. incorrect theorizing, inaccurate forecasts and unjustified policy conclusions. As with most conventional wisdom, the underlying truths are belied by exaggeration and become immune to challenge from the data. This is buttressed by the evident political appeal in such a critique of central planning.

These are not just academic disputes. It is important to get the macroeconomics of these countries right. Macroeconomic developments heavily conditioned the evolution of the Hungarian microeconomic reforms. Proper understanding of internal and external balance and the macroeconomic bases of trade and foreign borrowing was essential in foreseeing and interpreting CPE external debt problems and the Polish crisis (Portes, 1977b, and Marer, 1985). Those who took the conventional view of consumption as a "buffer" would have misunderstood CPE macroeconomic adjustment of the early $1980 \mathrm{~s}$. The proposition that investment cycles are the primary cause of macro disequilibria in the household sector would have been equaly misleading in interpreting the past several years. And as Stupnicki (1985) concludes in his Kornai-Portes comparison, "only Portes presents clues how to improve the situation". 
I have set out the theoretical innovations in Portes (1981. 1983). There are, however, equally significant practical lessons to be learned from eschewing the simple certainties of the "shortage economy" in favour of a more complex, more nuanced and better balanced view of the realities of CPE macroeconomics. 


\section{RE FERENCES}

Asselain, J. C., 1981, Mythe ou realité de l'épargne forcée dans les pays socialistes, in: M. Lavigne, ed., Travail et monnaie en système socialiste (Paris, Economica).

Alton, T. et a1., 1981 , official and alternative consumer price indices in Eastern Europe, Research project on National

Income in East Central Europe, $0 P-68$.

Barro, R. and H. Grossman, 1971 , A general disequilibrium mode 1 of income and employment, American Economic Review 61. $62-83$.

Barro, R. and H. Grossman, 1974, Suppressed inflation and the supply multiplier, Review of Economic Studies 41, 87-104.

Benassy, J. P., 1975, Neo-Keynesian disequilibrium theory in a monetary economy, Review of Economic Studies 42, 503-24.

Brada, J., 1982, Real and monetary approaches to foreign trade adjustment mechanisms in centrally planned economies. European Economic Review 19,229-244.

Burkett, J., 1985, Slack and shortage in socialist economies, mimeo, Brookings Institution.

Campbe11, R., 1970, Macroeconomic models and central pricesetting in the Soviet economy, in: Gehrels, F., et al., Essays in economic analysis and policy (Bloomington, Indiana University Press), 253-270.

Charemza, W., and R. Quandt, 1982, Models and estimation of disequilibrium for centrally planned economies, Review of Economic Studies 49, 109-116.

Charemza, W. and M. Gronicki, 1983, Rational expectations, wage illusion and consumption excess demand: an empirical investigation for Poland, Birkbeck College Discussion Paper in Economics no. 143 .

Clower, R., 1965, The Keynesian counter-revolution: a theoretical appraisal, in: Hahn, F. and F. Brechling, eds., The theory of interest rates (London, Macmillan).

Deaton, A., and J. Muel1bauer, 1980, Economics and consumer behaviour (Cambridge, C.U.P.).

Dlouhy, V., 1984, on the problem of macroeconomic equilibrium in centrally planned economies, paper presented to Econometric Society European Meetings, Madrid.

Duchene, G., 1984, Marchés parallèles et déséquilibre dans les economies socialistes, in: X. Richet, ed., Crises à l'Est 
(Lyon, Presses Universitaires de Lyon).

Farrel1, J., 1975, Bank control of the wage fund in Poland: 195070 , Soviet Studies 27, 265-287.

Galbraith, J. K., 1952, A theory of price control (Cambridge, Mass. Harvard University Press).

Gardner, R., and J. Strauss, 1981 , Repressed inflation in the Soviet Union, European Economic Review 16, 387-404.

Gomulka, S., 1985, Kornai's soft budget constraint and the shortage phenomenon: a criticism and restatement, Economics of Planning 19, 1-11.

Gourferoux, C., and G. Laroque, 1985, The aggregation of commodities in quantity rationing models, International Economic Review 26, 681-700.

Grandmont, J. M., and G. Laroque, 1976, On temporary Keynesian equilibria, Review of Economic Studies 43, 53-67.

Hansen, B., 1951, A study in the theory of inflation (London, Allen and Unwin).

Hare, P., 1982, Review article: Economics of shortage and nonprice control, Journal of Comparative Economics 6, 406-425.

Henin, P.-Y., 1984, Équilibres avec rationnement d'une économie à planification centralisée et secteur parallèle: une analyse macroéconomique, Document no. 90, UER Analyse et Politique Économique, Université de Paris I.

Holzman, F., 1956, Financing Soviet development, in: Capital formation and economic growth (Princeton: Princeton University Press for the National Bureau of Economic Research).

Holzman, F., 1960, Soviet inflationary pressures, 1928-1957, Quarterly Journal of Economics 74, 167-188.

Holzman, F., 1968, Soviet central planning and its impact on foreign trade adjustment mechanisms, in: Brown, A. and E. Neuberger, eds., International trade and central planning (Berkeley: University of California Press).

Howard, D., 1976, The disequilibrium model in a controlled economy: an empirical test of the Barro-Grossman model, American Economic Review 66,871-879.

Hulyak, K., 1982, Disequilibrium models for consumption goods in Hungary, paper presented to International Conference of Applied Econometrics, Budapest. 
Hulyak, K., 1983, An experimental disequilibrium macromodel for Hungary, mimeo.

Katz, B., 1979, The disequilibrium model in a controlled economy: comment, American Economic Review 69, 721-25.

Klaus, V., and V. Rudlovcek, 1982, Savings function as an inverse problem of disequilibrium consumption modelling: a case study of Czechoslovakia, paper presented to International

Conference of Applied Econometrics, Budapest.

Kooiman, P., 1984, Smoothing the aggregate fix-price model and the use of business survey data, Economic Journal 94, 899913 .

Kornai, J., 1980 , Economics of shortage (Amsterdam, NorthHolland).

Kornai, J., 1982, Growth, shortage and efficiency (Oxford, B lackwe11).

Malinvaud, E., 1977, The theory of unemployment reconsidered (Oxford, Blackwe11).

Malinvaud, E., 1981 , Econometric implications of disequilibrium theory, INSEE Working Paper no. 8114 .

Marer, P., 1985, Les relations commerciales Est-Ouest, Revue d'etudes comparatives Est-Ouest 16 , no. 3, 5-16.

Martin, C., 1986, Disequilibrium models with dispersed trading, Ph.D thesis, Birkbeck College, University of London.

Muellbauer, J., 1978, Macro theory vs. macroeconometrics the treatment of disequilibrium in macroeconomic models, Birkbeck College Discussion Paper in Economics no. 59.

Muellbauer, J., and R. Portes, 1978, Macroeconomic models with quantity rationing, Economic Journal 88, 788-821.

Neary, J. P., and J. Stiglitz, 1983, Towards a reconstruction of Keynesian economics: expectations and constrained equilibria, Quarterly Journal of Economics 98, 199-228.

Nove, A., 1979, Inflation in communist countries, in: Political economy and Soviet socialism (London, Allen and Unwin), 178191 .

Nissanke, M. K., 1979, The disequilibrium model in a controlled economy: comment, American Economic Review 69, 726-32.

Nuti, D.M., 1985, Hidden and repressed inflation in Soviet-type economies: definitions, measurement and stabilization, mimeo.

ofer, G., and J. Pickersgill, 1980, Soviet household saving: a 
cross-section study of Soviet emigrant families Quarterly Journal of Economics $94,121-44$.

Peebles. G. 1981, Money incomes and expenditures of the population of the Soviet Union: a East European comparison Hong Kong Economic Papers 14, 53-78.

Pickersgi11, J., 1976 , Soviet household saving behaviour, Review of Economics and Statistics 18, 139-47.

Pickersgil1, J., 1980 a, Repressed inflation and price controls in the Soviet household sector, Kennan Institute conference paper.

Pickersgill, J., $1980 \mathrm{~b}$, Recent evidence on Soviet household saving behaviour, Review of Economics and Statistics 62, 628-33.

Pickersgill, J., 1983 , Household saving in the USSR, in: Modigliani, F. and R. Hemming, eds., The determinants of national saving and wealth (London, Macmillan).

Podkaminer, L., 1982 , Estimates of the disequilibria in Poland's consumer markets 1965-1978, Review of Economics and Statistics $64,423-431$.

Podkaminer, L. 1984 , The political economy of permanent disequilibrium in Poland's consumer markets, mimeo.

Portes, R., 1974, Macroeconomic equilibrium under central planning, Institute for International Economic Studies, University of Stockholm, Seminar Paper no. 40 .

Portes, R., 1977 a, The control of inflation: lessons from East European experience, Economica 44, 109-130.

Portes, R., $1977 \mathrm{~b}$, East Europe's debt to the West, Foreign Affairs 55, 751-782.

Portes, R., 1979, Internal and external balance in a centrally planned economy, Journal of Comparative Economics 3, $325-$ 345 .

Portes, R., 1980 , Effects of the world economic crisis on the East European economies, The World Economy 3, 13-52.

Portes, R., 1981, Macroeconomic equilibrium and disequilibrium in centrally planned economies, Economic Inquiry 19, 559-78.

Portes, R., 1983, Central planning and monetarism: fellow travellers? in Desai, P. ed., Marxism, central planning and the Soviet economy (Cambridge, Mass., MIT Press), 149-65.

Portes, R., and D. Winter, 1977, The supply of consumption goods in centrally planned economies. Journal of Comparative Economics $1,351-365$. 
Portes, R., and D. Winter, 1978, The demand for money and for consumption goods in centrally planned economies, Review of Economics and Statistics 60, 8-18.

Portes, R. and D. Winter, 1980, Disequilibrium estimates for consumption goods markets in centrally planned economies, Review of Economic Studies 47, 137-159.

Portes, R., R. Quandt, D. Winter, S. Yeo, 1983, Macroeconomic planning and disequilibrium: estimates for Poland, 19551980 , NBER Working Paper no. 1182 .

Portes, R., R. Quandt, D. Winter, S. Yeo, $1984 \mathrm{a}$, Planning the consumption goods market: preliminary disequilibrium estimates for Poland 1955-80, in: Malgrange, P., and P.-A. Muet, eds., Contemporary macroeconomic modelling (Oxford, B (ackwe11), 254-271.

Portes, R., R. Quandt, D. Winter, S. Yeo, 1984b, Estimating the size of plan errors, Princeton University Financial Research Center, Research memo no. 48, appeared (in French) in Annales de l'INSEE 55/56, 245-255.

Portes, R., R. Quandt, and S. Yeo, 1985 , Testing the "al1-excessdemand" hypothesis, mimeo.

Pryor, F., 1977, Some costs and benefits of markets: an empirical study, Quarterly Journal of Economics 91, 81-102.

Quandt, R., 1978, Tests of the equilibrium vs. disequilibrium hypotheses, International Economic Review 19, 435-452.

Quandt, R., 1982, Econometric disequilibrium models, Econometric Reviews $1,1-63$.

Skurski, R., 1972, The buyers' market and Soviet consumer goods distribution, Slavic Review 31, 817-830.

Stupnicki, K., 1985 , The disequilibrium theory: R. Portes v. J. Kornai, a critical comparison, Working Paper 2, Institut Cybernetyki i Zarzadania, Szkola Glowna Planowania Statystyki, Warsaw.

Tartarin, R., 1982, La théorie du déséquilibre appliquée aux économies du type socialiste, mimeo.

Timmer, J., 1982, Disequilibrium and buffer stocks, Erasmus University.

Turcan, J., 1977, Some observations on retail distribution in Poland, Soviet Studies 29, $128-136$.

Weinrich, G., 1984 , On the size of disequilibrium in an equilibrium with quantity rationing, CORE Discussion Paper 
No. 8418 .

Wiles, P., 1982, Inflation in USSR 1982, paper presented to NASEES Conference.

Wiles, P., and J. Rostowski, 1979, Soviet type inflation: an open debate, Est-0uest $10: 2 / 3,59-75$.

Winiecki, J., 1985, Portes ante portas: a critique of the revisionist interpretation of inflation under central planning, Comparative Economic Studies 27, 25-52.

Wolf, T., 1985, Economic stabilization in planned economies, International Monetary Fund Staff Papers, 32, 78-131. 